It seems reasonable to admit, as Dr. Vaughan does, that the association of ammonifying bacteria with others producing carbon dioxide may result in the formation of ammonium carbonate, which, reacting with calcium sulphate in solution, causes the precipitation of calcium carbonate. Dr. Vaughan points out, however, that the surface layer of oceanwater in tropical and subtropical regions is saturated with calcium carbonate, and that evaporation during the summer months is sufficient to account for the precipitation of calcium carbonate, without the agency of bacteria. Taking the evidence as a whole it seems legitimate to infer that, although bacterial precipitation is possible, it is quite unimportant as a cause of deposition of calcium carbonate even under the most favourable conditions, and that bacteria cannot compare with foraminifera, corals, molluscs, and nullipores as limestone builders. THOMAs CROOK.

\title{
The German Scientific and Medical Association Meeting at Innsbruck.
}

THE German Scientific and Medical Association -Gesellschaft deutscher Naturforscher und Ärzte-held its eighty-eighth meeting in Innsbruck, Austria, on September 2I-27. Many former members are now technically foreigners, domiciled in places once Germany, now called by other names. Hence a curious sort of superimposed internationality on a German-speaking basis, a formal recognition of foreign members, and a need for passports. The Austrian embassies and consulates offered visas free of charge from Berlin, Rome, Prague, Belgrade, Budapest, Buckarest, Bern, Danzig, Copenhagen, Stockholm and Christiania. A very emphatic welcome was given in Innsbruck by the Austrian President, Dr. Hainisch, in the name of the republic, and by Dr. Schneider, Minister of Education, for the Government and by others. There were more than 7000 ticket-holders, including a very few Englishmen, among whom were Prof. G. H. Hardy from Oxford and Prof. G. Barger of Edinburgh. The organisation arrangements seemed excellent. The programme was a pamphlet of 24 quarto pages with a very long list of papers, well cross-referenced to joint sessions, and mutual invitations between the 33 separate sections. The ground covered was similar to that of a British Association plus a British Medical Association meeting. The professors of the University of Innsbruck have fitly inaugurated their new buildings. All who co-operated with them, not forgetting the schoolboys who handed out programmes or wore ribbons and met travellers at the station, are to be congratulated highly on the success of their efforts.

The more popular addresses, corresponding to British Association evening lectures, were taken on the first three mornings of the week. These included Dr. Penck on the aspect of the Alps, Dr. Sommerfeld and others on the Bohr atom model, Dr. Porsch on the pollination of flowers by birds, and Dr. von Frisch on the senses and "language" of bees. Experiments have been made in training bees to feed on coloured paper. They appear to recognise colours, including violet, but scarlet is as black to them. The flower-birds visit bird-flowers with the same range of colours as their own plumage; these include red, yellow, and blue. Dr. Knoll has been watching the humming-bird hawk-moth by a proboscis-track method. He finds that after visiting one flower it leaves tiny traces of sugar water on the next object it touches. Dr. Frisch has follower the bees more exactly in an observation hive where each separate insect was marked and numbered consecutively. He says that bees finding honey report their luck to the hive by a special waddling dance. Their comrades are then stimulated to go out and hunt for flowers with the same scent as the honey brought home.

Among numerous communications to the sections were papers on cellulose, the rôle of alkaloids in the life of plants, sweet taste and chemical constitution, fractional distillation and the non-separation of chlorine isotopes, electrolytic conduction in molten alloys, the fine structure of fibre stuffs, on cyanamides, cyanogen compounds, the electric iron industry in the Tyrol, rapid telegraphy in ocean cables, the Siemens band-microphone, electric conductivity in rock salt and calc spar at high temperatures, quantitative spectrum analysis, the measurement from aeroplanes of radioactive decay products in the air, the formation of nitric oxide in the electric arc, the structure of the earth at different depths deduced from earthquake wave velocities, earth currents in mountains, deformation of individual crystals, microchemical detection of complex iron compounds in living plant tissues, and so on.

A joint meeting of Section I., Mathematics, and Section XV., Mathematical and Scientific Instruction, has considered the Denkschrift (Memorandum) of the Prussian Ministry of Education on the reorganisation of higher school education in Prussia. The Union of German Mathematical Societies and the German Committee for Mathematical and Scientific Instruction have also assisted. The hours allotted to mathematics and science, out of a weekly total of 29 , are, in the higher forms of the Gymnasium, 3 and 2 ; in the Real-Gymnasium, 3 and 4 ; in the Reform-real-gymnasium, 3 and 3 . A minimum of 4 hours weekly for mathematics is demanded. Since the days of Kant, a Weltanschauung without mathematics is impossible ; it is a training in conscientiousness and fidelity in detail. Science is not merely necessary for all higher specialised work, but is a necessary element of culture. It is a discussion about hours in the curriculum such as we knew in England a generation ago. In Berlin the history teachers are also perturbed about the Memorandum. It is a matter of rescuing humanity in the largest sense from the humanities in their narrowest meaning. Both aims and methods in education need humanising.

The interest of the meeting was intensified by simultaneous gatherings of other societies in association with particular sections. Such were the German Mathematikervereinigung, the Gesellschaft für angewandte Mathematik und Mechanik, the Gesellschaft für Epidemiologie, the Kolloid-Gesellschaft, the Gesellschaft für Kinderheilkunde.

A long series of excursions, especially for geographers and geologists, had been arranged for the days before and after the meeting. For some of these, early notice had to be given, as numbers were limited and clear instructions necessary- " only for good walkers . . . 7 hours a day ... bring food .. climbing boots . . . hotel meals only in evening perhaps only hay-shed."

There were several exhibitions, the exhibits being chiefly by German and Austrian firms, a large collection of new scientific books, scientific and medical apparatus especially for Röntgen rays and synthetic drugs. The schools showed some exceptionally good geometrical drawing, a subject to which great importance is attached. The most attractive exhibit was a film showing the movements of growing plants by the Badische Anilin- und Soda-Fabrik. Photo-

NO. 2872 , VOL. I I 4$]$ 
graphs had been taken at 20 minutes' intervals and the film speeded up. There are plotted diagrams in Darwin's " Movement in Plants," but none of us had ever seen such extraordinary gesticulations before.

Funds did not allow of printed abstracts in advance, but very successful arrangements were made by the Press Bureau. Proof sheets containing the more popular parts of the day's work were ready at the end of the afternoon and were widely distributed to the press. More technical papers were represented by typed abstracts.

\section{The Chemist and the Fermentation Industries.}

\section{Streatfeild Memorial Lecture.}

THE annual Streatfeild Memorial Lecture was delivered at the Finsbury Technical College on Nov. 6 by Mr. Julian L. Baker, who selected as his subject "The Chemist and the Fermentation Industries." It was pointed out that the revenue from beer and spirits accounts for about one-sixth of the total expenditure, and the materials from which beer and spirits are made are almost wholly derived from agriculture and for the major part from materials grown in Great Britain. It will, therefore, be apparent that the commercial products of fermentation are derived from biochemical industries of vast extent and of enormous economic value. The very small amount of exact knowledge concerning the changes which starch and proteins undergo during the preparation of malt from barley and the mashing process was referred to, also the difficulties which underlie such investigations. An outline was given of work being conducted under the auspices of the Research Scheme of the Institute of Brewing. Much of this is being done at the Rothamsted, Wye and East Malling Research Stations under the direction of Sir John Russell, Mr. Salmon and others. Prof. Pyman, of the Municipal School of Technology, Manchester, is responsible for the chemical work on the constituents of hops, and the direction of other researches is entrusted to certain other college laboratories.

It is not easy to convince the principals of an industry which is essentially empirical in character that, as knowledge increases, the old order pari passu changes. The British instinct is to leave well alone. The endowment of research should be regarded by manufacturers as an insurance. Neither is it reasonable for an industry to expect results from scientific researches which will affect immediately manufacturing operations, or an improvement of output. The success of a brewer is gauged by his product, and, as he is essentially a craftsman, his reluctance to experiment on anything but a small scale can be understood. Such considerations as these militate in no small degree against the generous financing of research.

Reference was made to the manufacture of alcohol and to the "Amylo" process, which cannot be used in England owing to regulations enforced by the Board of Customs and Excise; also to the products, such as glycerol, formed by $S$. cevevisia from sugar under certain abnormal environmental conditions, and the production of lactic and butyric acids from sugar by bacterial fermentation. The industries based on the activity of micro-organisms are of profound importance to the community, and the fields of investigation both academic and technical in such industries are limitless.

At the conclusion of his lecture, Mr. Julian Baker referred to the recent decision of the City and Guilds of London Institute to close the College in I926. The withdrawal of the London County Council grant of Io,oool. per annum, to take effect in I926, was largely responsible for the position. He thought the decline in the number of students, given as a reason for the grant withdrawal, had been unduly exaggerated and was no greater than might be anticipated in view of the action taken in 1920 to close the College and admit no new students in the session I920-2I. Immediate action was necessary on the part of those who valued the real and practical educational facilities offered by the College for the last 46 years, due in the first instance to the curriculum provided in chemistry and engineering by its first teachers, Armstrong, Perry and Ayrton. The practical courses unfettered by any particular examination syllabus should be continued, and it was to be hoped that an influential deputation of manufacturers and educationists would find a way to enable the College to continue its work.

Mr. A. Chaston Chapman considered that the sound practical training, with freedom from examination syllabuses, the great tradition of its past students and teachers, and the service it has rendered should assure the continuance of Finsbury, while Prof. G. T. Morgan pointed out that the goodwill of the College and traditions associated with it could not be continued elsewhere.

Prof. H. E. Armstrong gave an account of his early work at Finsbury with Perry and Ayrton, and emphasised the value which the training had always had in promoting the application of science to industry. The College started under the influence of men like Sir Frederick Bramwell, Lord Halsbury and Sir Owen Roberts, and the courses for training chemists and engineers were unique. Chemical engineering was no new subject at Finsbury. All its chemists received training in the principles of engineering as part of the ordinary course.

Prof. F. G. Donnan, who was unable to be present, sent a letter, in the course of which he said : "The whole cause of higher education in London is suffering at present from the want of autonomy in the principal colleges as regards the examination for the B.Sc. Degree. The old Finsbury system was and is the only one which produces good results, and is in fact the method employed by other civilised countries with the exception of England." Mr. F. H. Carr, who also spoke, agreed that the training offered at Finsbury was of great value to the industries. He considered that we are suffering greatly from what he termed the respectability of degrees.

Mr. A. J. Chapman, president of the Old Students Association, gave an interesting account of the work now being done by the Association to save the College.

\section{University and Educational Intelligence.}

CAMBRIDGE.-The Botanic Garden Syndicate reports that with the aid of a further generous gift from Mr. Reginald Cory, it is proposed to provide a house for the Director of the Garden. The Local Lectures Syndicate has presented its fifty-first and last report, it having been superseded by the new Board of ExtraMural Studies. The report makes reference to the loss suffered by the cause of adult education through the death on Mount Everest of Mr. Leigh-Mallory, Assistant Secretary for Lectures, and also through the death of Prof. H. V. Stanton and Prof. R. G. Moulton.

The Lees-Knowles lectures on military science are being given by Lieut.-Col. F. Nosworthy, on Russia before, during, and after the Great War.

Mr. D. R. Hartree and Mr. E. A. Watkins have been elected to fellowships. at St. John's College.

The following have been elected to serve on the

NO. 2872 , vOL. I I 4$]$ 